\title{
THOUGHTFUL RECOVERY OF MEDIEVAL SHIPYARDS IN CONTEMPORARY CULTURE SITES
}

\author{
ANTONELLA GUIDA, ANTONELLO PAGLIUCA \& DOMENICO DEBENEDICTIS \\ Università degli Studi della Basilicata, Matera, Italia.
}

\begin{abstract}
There is architecture that could be called "timeless": places built by ancient civilizations where transformative human interventions have been successful; in fact, despite making small changes related to new needs, they have allowed the preservation and maintenance of this architecture. The shipyards of the Mediterranean can certainly be connoted as "timeless" places; they are characterized by simple structures, as they are factories and buildings without value; at the same time, they are imposing buildings, as they include other minor construction yards for the construction of vessels. They became an economic and social way to develop the culture of a site. These buildings are witnesses of an architectural monumentality that, although medieval, nevertheless displays a contemporary conception of space: great depth, good perspective and arches that seem to chase each other. This is the reason why, despite time, these buildings have always managed to perpetuate in new and different functions. This research analyzes the role that these places currently perform; the redevelopment and recovery processes that are submitted to ensure that this architecture continues to dialogue with the historically consolidated urban contexts, responding to the needs of contemporary living (i.e. from naval factories to factories for culture). The project of "controlled modification", to which this architecture is now subjected in order to go on living, belongs to the knowledge or methodological approach which allows space and time to be given to these places and also to their particular production and commercial importance.

Keywords: mediterranean basin, recover \& valorization, shipyard, space versatility.
\end{abstract}

\section{INTRODUCTION}

In the Middle Ages, the buildings that defined urban complexes were formed, on the one hand, by a scattered and varied domestic architecture and, on the other, by fine architecture marked by the centers of political power - the castle and then the palace - and of religion: the cathedral; these construction sites become, for a period, the economic driving force of a city or even of an entire region. It was in this period, in fact, that new techniques were developed that allowed the construction of majestic buildings.

The architectural majesty, however, belongs not only to these categories but also in buildings of purely industrial character. Naval arsenals undoubtedly belong to this further class, in fact they are group of buildings characterizing urban centers developed in the Mediterranean coastal areas or on the banks of navigable waterways.

The shipyards are generally composed of a simple structure, marked by elementary arch and truss systems, which, however, outline-ample and powerful spaces. Construction sites like this should certainly appear similar to their contemporary counterparts; Spanish historian, Pablo Pérez Mallaína, describes the shipyard of Seville as being like a mosque, for its mudéjar style [1]. In this era, the development took place of the most important projects in respect of military and commercial vessels, which transformed the Mediterranean Sea into the main location for naval engineering.

The way in which this era ended and the time at which it ceased differed from arsenal to arsenal for individual reasons; with its end you see the cessation of the activities for which these buildings were designed. In spite of this, the facilities have come down to us, after 
almost 800 years of history, in which they saw kaleidoscopic changes of use. These places, which seem to be bestowed with an anonymous spatial conception, are like skeletons, on which different uses took turns and which new uses seem to want to adapt.

\section{NAVAL FACTORY ON THE MEDITERRANEAN BASIN}

The arsenals have been responsible for the devolopment of the major port cities that are currently in the western Mediterranean countries: Italy, Spain, France, and the eastern Mediterranean countries, such as Croatia or Turkey, as well as all those on the coast of Africa, dominated in the Middle Ages by the various Arab dynasties that gave strong impetus to the construction of these industrial facilities.

The port cities constituted strategic points throughout the territory in question, so as to create a network of connections to facilitate communication by sea, thus marking the trade routes that favored the exchange of goods that the various populations were interested in exporting or importing. In this way, the arsenals, as well as being constructed to acquire military fleets, represented the starting point of a political and socio-economic process that involved much of the population of these cities, whose members held different tasks and roles, depending on the competencies and skills they possessed. In this sense, the arsenals, both during construction and with the subsequent practice of the shipping industry, were able to create a larger and more complex system than what we understand today by a medieval factory. They saw, in fact, the involvement of all those craft activities associated firstly with wood, but also with the production of ropes, fabrics for sails, tools to produce all those elements in iron (ranging from smaller items, e.g. nails for junctions, up to anchors or large guns), in addition to the preparation of foodstuffs to be cooked on each vessel to ensure nourishment in the face of long and risky travel.

In relation to all these activities, also, in each city, the various naval powers provided mutual agreements in order that they might own the areas inside the walls to install buildings, called fondachi, for the storage and sale of goods, in addition to granting accommodation for the foreign merchants [2].

Arsenals found in key locations, however, more or less distant from the urban center, usually presented themselves as an extended complex of buildings. Although, from the architectural point of view, the type is similarly repeated across the entire Mediterranean, reproducing the Greeks' neoria and the Romans' navalia, the configuration varies, depending on the importance and magnificence the port acquired over the centuries.

To the Serenissima belongs, without doubt, the most vast and articulated arsenal of the time. At the height of its splendor, Venice saw an extension on its eastern end of a real neighborhood, the result of additions of different buildings for morphology, type and function, around a polygonal dock connected by two gates, one leading towards the inside of the city (Porta di Terra) and the other towards the Adriatic Sea (Porta d'Acqua) [3]. Smaller, but very important, are the arsenals of the Republic of Pisa (Fig. 1 left); these were arranged around an artificial harbor, connected, in this case, through a gate (called delle Galee) to the right bank of the Arno River. Of ancient Terzana, the name given to that place by the people of Pisa, only four of the original 60 to 80 aisles remain; built against the wall for the storage of galleys, they fortified the city for half the 13th century on the other sides [4]. Further south, still on the Italian peninsula, on the Tyrrhenian coast, Amalfi was also equipped with a shipyard (Fig. 1 right). Originally composed, according to a hypothesis, of only threeaisles, which stretched toward the coast with its facade in direct contact with the water [5], it now has two, divided by ten pillars. 

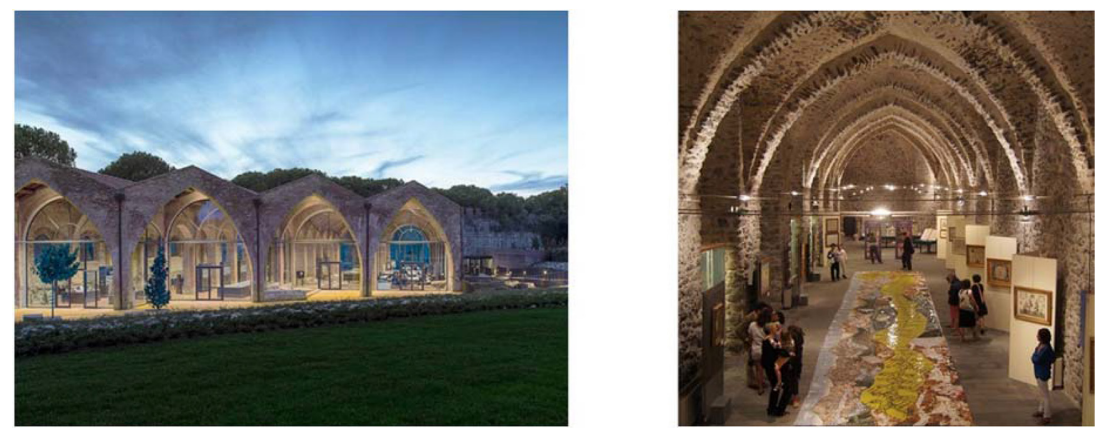

Figure 1: Republican Pisa (left) and Amalfi (right) dockyards.

Similar industrial complexes were built in the Iberian territories. In Valencia, there are five aisles in the Grao district. Grao was originally a settlement near the sea that depended on the city, built away from the coast due to the hostility of the territory. Around the 14th century, with the growing naval activities, it was decided to provide this settlement with an arsenal (Fig. 2 left). This was not just made up of the aisles but also of other structures, such as large tanks of water for the preparation of wood for the construction of boats, warehouses and a noble house, typical of the residence of the inspector of the yard's activities [6]. In Andalucia, on the west bank of the Guadalquivir river, also in Seville, las Reales Atarazans can be found (Fig. 4): an entire block that today is heterogeneous mixture because of the transformations that the arsenal has suffered over the centuries. It is an arsenal that at its completion consisted of 17 aisles, perpendicular to the watercourse, of which the five southernmost were torn down in the middle of the last century, those in the center having been transformed and adapted for a hospital complex and a church in the modern age, while, in the seven northernmost aisles, one can still perceive the appearance, although altered in part, it had in medieval times [7]. Another arsenal belong to the city of Barcelona (Fig. 2 right). Consisting of a great complex of eight aisles, currently seven because the two central were merged into one, it represented the most important shipyard in the kingdom of Aragon and one of the leading arsenals in the western Mediterranean [8].

If you travel on the Eastern Front you encounter other examples of naval arsenals; one such is Tersane of Alanya (Fig. 3 left), located on the east coast of the Gulf of Antalya, Turkey. A peculiar model of a yard, its five aisles are in direct contact with the water [9]. Thanks to this
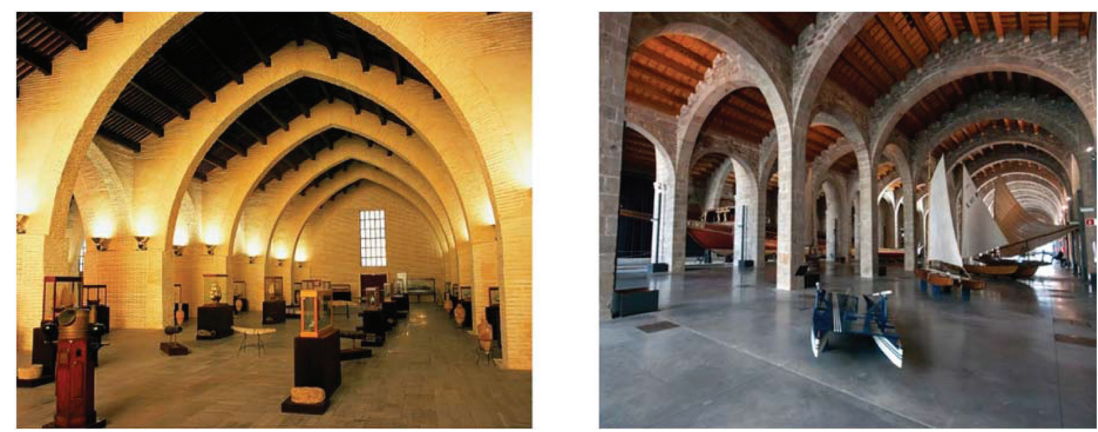

Figure 2: Interiors of Valencia (left) and Barcelona (right) dockyards. 

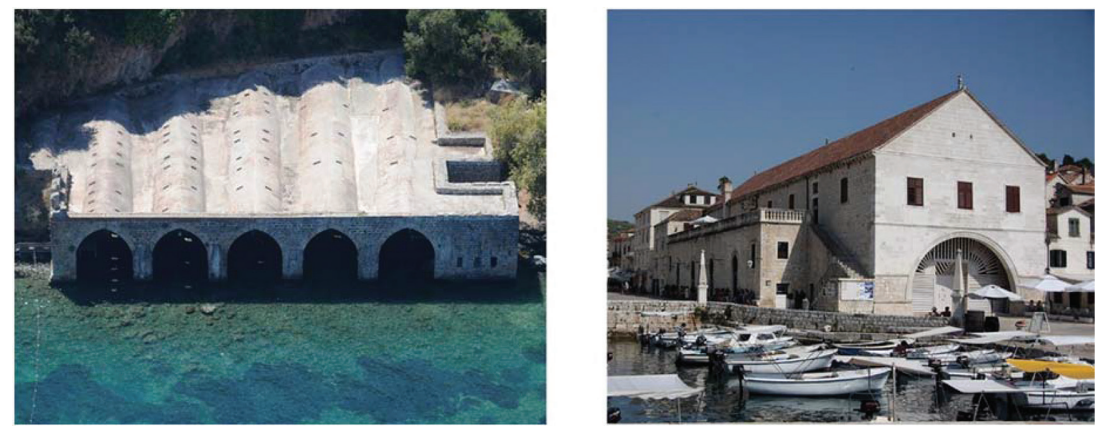

Figure 3: Alanya (left) and Hvar (right) dockyards.

configuration, it allowed easy and convenient maneuvering for entry to and exit from the arsenal of boats; although modest in size, this made it unique. In Croatia, in the main center of the island of Hvar, in the late 13th century, Venice ordered the construction of a shipyard for the galleys; this fell to ruin through the wear and tear of time. It was replaced in the 16th century by a shipyard (Fig. 3 left) with a single large nave, spaced out by seven majestic arches, surmounted by a further elevated space enclosed by a wooden truss structure [10].

As can clearly be seen, there are many factories of this kind, more or less large and articulated, that are still located today across the entire territory of the Mare Nostrum.

\section{ANONYMOUS STRUCTURES WITH VERSATILE SPACES}

Bricks and blocks of stone and small-sized elements, ingeniously arranged and fastened to create rows of massive piers, connected by arches: elements that follow one another repeating in parallel series, blending together with complementary substantial wooden structures. Traditional elements of architecture, built with expert and ancient techniques of construction have generated sites that to any eye appear charming and fascinating. Thus appear naval arsenals: simple and essential structures, defined, in most cases, by an orthogonal grid of pillars that develops in a longitudinal sense to form rectangular areas, in which commercial or war boats took shape.

Although structurally simple, the configuration of a naval arsenal, without any decoration, makes the rhythmic and repetitive succession of arches and pillars produce exemplary perspective games in any direction. It is this feature, that of greater formal value attributable to these buildings, which makes them, therefore, unique and exciting. The spaces, thus generated, although unconsciously, are an absolutely contemporary concept, compared to the architectural theme that is in search of more and more spaces that are versatile and adaptable to different purposes. The test of time, in fact, is the demonstration of how such structures, even after the loss of their principal function and despite the low aesthetic value, have not undergone demolition but have seen a succession of transformations and changes of use, to which it seems they are always well adapted.

From their origins as naval factories, the spaces have been used as warehouses for wheat, for wool, for mercury, etc. In the case of Seville, the first aisle, the northernmost, was converted into a fish market [11], dividing it into multiple small stores, arranged on the long sides by creating a central passage: a real covered market. Many of the arsenals were converted from naval to military use, providing for the manufacture of artillery with annexed places for military training, as is the case of the arsenals of Barcelona or Pisa. The latter, for a period, 
was identified as the "cittadella", because of its military function. The uses to which the arsenals have been put, however, are not only in the area of productive activities but also cultural; in fact, an aisle of the arsenals of Valencia was used as a cinema room, while, since the beginning of the 19th century, the upper floor of the arsenal of Hvar has housed a small theater, consisting of an auditorium with loggias.

Today, the project directives seem to be changing, thanks to a strong process of awareness of historical architectural heritage; this is definitely converting these factories from industrial to cultural centers.

\section{NEW PROJECTS FOR ANCIENT PLACES WITH CONTEMPORARY SPACES}

The transformations and changes in usage suffered by these arsenals, in some cases, have been consolidated in the present day, while, others, especially after the two world wars, have been lost, causing improper use of the sites or even abandonment. Only when the concept of historical and artistic heritage extends not only to the main monuments of the city but also to buildings with a historical-technological and socio-cultural value, will naval arsenals return to the center of attention in historical port cities. These were greatly impaired buildings, obsolete and altered in morphology, so much so that, in some cases, the result was that it was difficult to read the original structure.

As techniques and technologies of naval architecture have evolved so much, changing the logistics of production and trade, we have seen the need to move industrial facilities outside residential areas. So, the historical buildings, which now present themselves as modest and unsuitable spaces for today's naval techniques, remain huge and interesting for the parallel activities of the new way to experience the city: the city which belongs not only to those who live here but also to all those tourists and travelers who journey in search of knowledge and to discover different cultures, visions, perceptions and ideas.

According to this logic, historic urban centers, dense and intricate plots, are forced to adopt large containers for use as city museums [12]. In the case of port cities, however, it was thought good to convert the grand spaces of the arsenals. Now, incorporated into the historic urban fabric, besides themselves telling the story of the city, within, they host exhibitions and cultural activities at the local, national and even international level.

The modern uses for historical, naval arsenals as destinations depends on both the size of the spaces and their potential and, finally, on the social and economic policies that characterize the individual cities in which they are located. It is certain that the original function could not be restored; with this in mind, these classifications can be found, according to the new destinations:

- Naval museum and museum of the city-harbor;

- Cultural center, art exhibitions and workshops;

- Specialized centers for boating and marine innovation;

- Spaces still unused and waiting to be recovered.

In particular, the arsenals of Amalfi, Barcelona and Alanya have been converted into museums with replicas of ancient galleys, tools and objects related to the art of shipbuilding, as well as documents that can relate and clarify to visitors the evolution of maritime knowledge during the Middle Ages. The arsenals of Pisa, Valencia and Hvar have been restored and are used as versatile spaces, alternating as exhibition centers for various art and cultural initiatives, interactive workshops, or as tourist information centers. Despite the many failed 


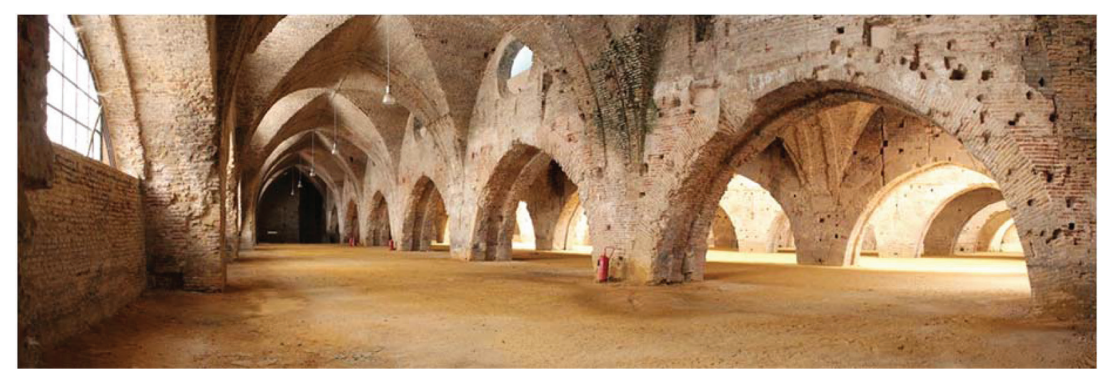

Figure 4: Interior space of Reales Atarazans in Seville.

attempts to construct a cultural center, Las Atarazanas of Seville remains at the center of a controversy because of a debate regarding the definition of the floor surface.

Because of the vastness and the complex set of arsenals and following a recovery and renovation process, although slow, the case of Venice is characterized by ingenious and original architectural interventions. Besides making the spaces of the Corderie, Artiglierie, Tese of the XVI and dell'Isolotto usable and functional, through the Biennale, among the most famous and prestigious cultural institutions in the world (with several cultural activities like shows and exhibitions), they are putting in place projects with the goal of reconnecting the arsenal to the city. MAP Studio's project (2009-2011) for the Porta Nuova Tower hoisting machine, in addition to ensuring the preservation and enhancement of the building, combines the need for further exhibition and cultural center space in the Darsena Novissima area. The key objective of the project was the introduction of a modern vertical path in Cor-Ten steel, alternating stairs, ramps and walkways, parallel to the ancient wooden ones recalling Piranesi's drawings, which links the conference room on the ground floor and an exhibition space at the top, also treated and coated with the same material (Fig. 5).

Also, among the most advanced projects are included those of the Tesa 105 recovery, which is the new entrance to the north of the arsenals, where there are facilities for a research center (the work of architects Holguin - Morales - Solis, realized in 2012). In the inner space of Tesa, considered as empty, a steel and glass autonomous structure has been created in contrast to the brick that surrounds it. The new building is designed in the same way as that by which the boats were realized: raised on a few supports. Small spaces on the lower level
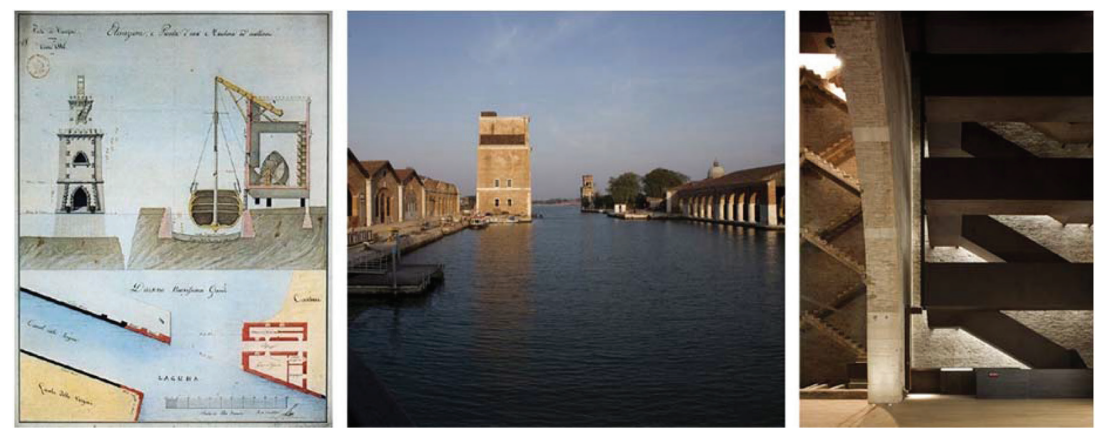

Figure 5: Elevation and plan of a "hoisting machine", Paris, Archives Nationales and Torre Porta Nuova recovery project (pictures from http://www.map-studio.it/). 

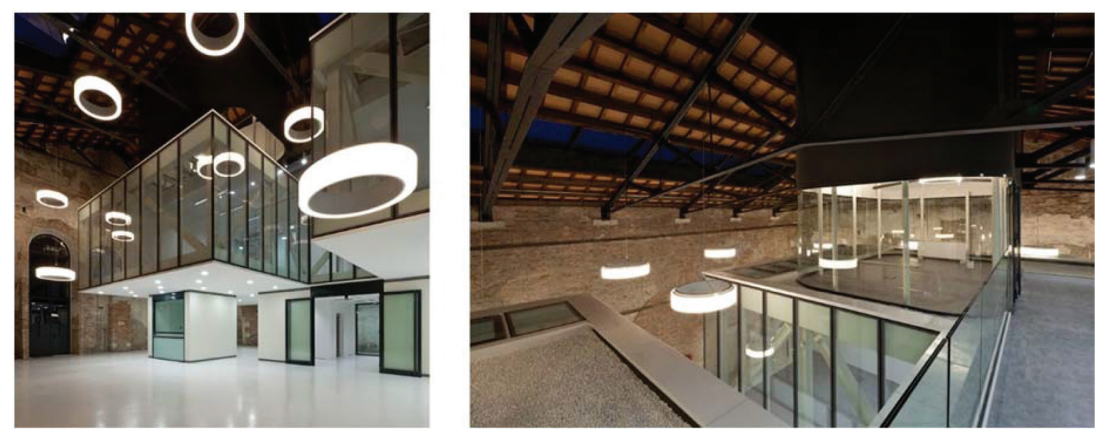

Figure 6: Recovery project of Tesa 105, Venice (pictures from http://www.studioglass.it/).

support those of larger size in which the offices are distributed. On the top level, two glass spaces embrace the covering structure of the iron truss, defining the meeting rooms (Fig. 6).

The Lamierini shed was designed as a center specializing in marine and coastal technologies (made by Alberto Cecchetto in 2002); instead, a kind of vessel of a contemporary curved shape, whose base is predominantly matte, coated steel, polycarbonate and glass, has been inserted, while the upper body is transparent, allowing a view of the interior space of the shed. The whole structure is placed close to one side of the brick wall, leaving free an open space for the movement of materials and laboratory machinery (Fig. 7).

Finally, we consider the transformation of a structure in the arsenal station of Venice's harbor door control (project conceived and developed by $\mathrm{C}+\mathrm{S}$ Architects in 2011). Here, the place that most thought would be dedicated to the operators has been reshaped to accommodate the computer terminals for the management of marine traffic. This is an ambitious project that means that, due to the constant updating, the Venetian arsenals are still capable of continuing their naval activities in a new technological way. The room is occupied by a single cuboid building for sanitary facilities, also in this case in Cor-Ten steel, called Relitto, accompanied by a fissure on the floor; a staircase leads to the data processing center. Moreover, all of the glass cover systems are equipped with sophisticated technologies for the production of energy, showing that interventions for the recovery of historic buildings can be combined with those for environmental sustainability (Fig. 8).
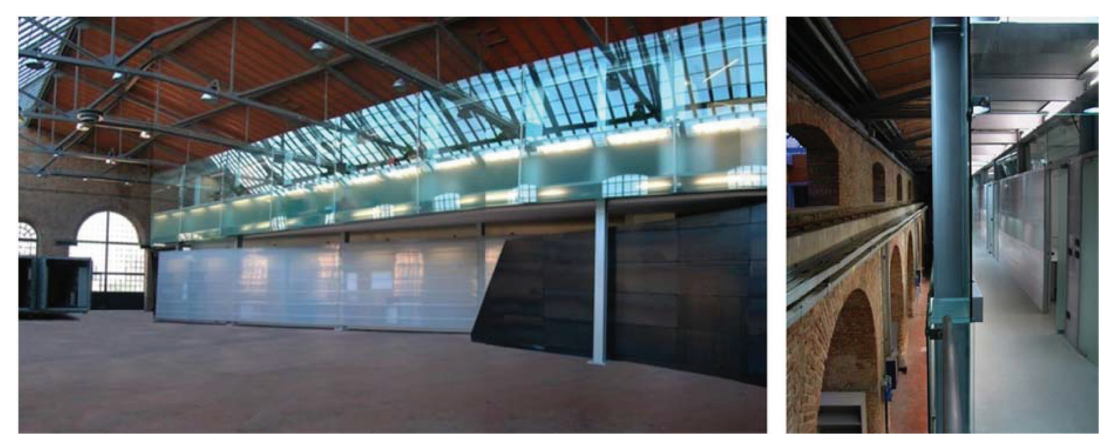

Figure 7: The new structure built into the Lamierini warehouse, Venice (pictures from http:// www.studiocecchetto.com/). 

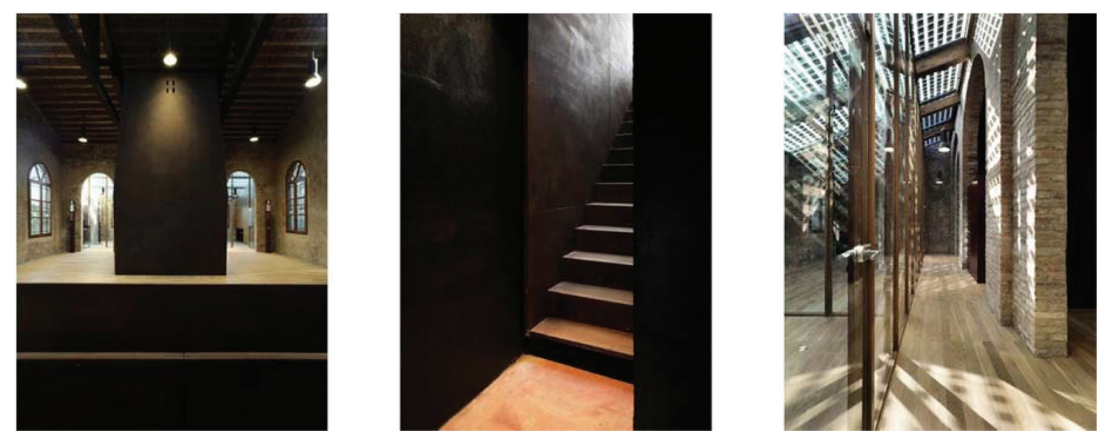

Figure 8: Harbor Brain Building in Venice's Arsenale (pictures from http://web.cipiuesse.it/).

\section{NAVAL ARSENALS: ARCHITECTURAL STRATEGIES FOR CONSERVATION AND VALORIZATION}

The contemporary interventions performed on the arsenals' structures range from pure restoration, to works of consolidation and maintenance, up to a recovery of the interior spaces; in any case, they are carried out so that the arsenals maintain their identity, independent of any new use. The tendency is to free the interior of any partitions that are incongruous, restore the missing parts of the original structure, preferably using original materials found in situ, and clean up the elements, bringing to light the fairfaced stone materials, and, where necessary, deciding on the replacement or repair of wooden roofs, which in most cases are damaged and strongly degraded. In so doing, one tries to obtain a picture, which is, as far as possible, uniform and clear, so that the majestic feel of the place can be perceived, consistent with what the original shipbuilding factory was supposed to look like.

Restoring the formal image, one also tries to suggest the scenic atmosphere of all the activities carried out in the yards. It is for this reason that many of the historical arsenals have been converted into naval museums; large vessels, from archaeological excavations or mere reproductions, are inserted into the aisles, returning the authentic feel of the ancient art of shipbuilding. The goal is to return the arsenal in its entirety to life, although users-to-be are not masters or arsenalotti but visitors who immerse themselves in the past to discover the medieval world of navigation.

However, recently, in the great and mighty arsenals of Venice, they have experienced real recovery operations, which, in addition to providing maintenance, are intended to redevelop the entire complex so that it can come back, brimming with life. In this case, it is unthinkable to convert the entire Arsenale into a museum; the idea is to transform this structure into a suitable space for the community [13].

This strategy leads to the addition of new elements to the old structures: autonomous objects, with new structures, independent from the originals, distinct and recognizable materials and technologies with respect to masonry walls. Consisting of steel elements, coated glass and Cor-Ten, they are assembled dry, according to the logic of reversibility. They are structures, designed with the same concept as that of the boats: assembled through joints, they remain independent from the architecture that protects them.

\section{CONCLUSIONS}

There is some architecture that could be called "timeless": places built by ancient civilizations that have won over man, who, although making small changes according to the new requirements, has allowed their preservation and maintenance. 
There is no doubt that the arsenals can be denoted as "timeless" places; conceived as shipyards for shipbuilding, it was with this purpose in mind that simple structures had to be designed, because they were industrial rather than prestigious buildings. At the same time, however, they were impressive, because their interiors had to accommodate many minor sites for the construction of boats.

Despite the construction techniques in masonry, the arsenals are still defined by serial elements: slender pillars and arches draw "frameworks", in brick or stone ashlars, which mark an architectural rhythm, as the Perret and Le Corbusier buildings in reinforced concrete, in which the main character is just the framework structure, which allows complete flexibility of space.

In the arsenals, in fact, we can find, paradoxically, some of the famous five points of Le Corbusier:

- the most obvious is that of the "free plan", which is free of structural walls and consists only of pillars that allow, on the one hand, the full perception of space and, on the other, an easy subdivision of it, according to the various needs;

- the facade is "free"; in fact, if the arches were originally kept open to allow the passage of boats, then they were, in many cases (Seville, Valencia), walled up, not only by simple closings that would allow the use of the interior space but also by imposing facades. Today the arches are once again gutted and left empty or even equipped with huge windows (the arsenals of Pisa, for example) running from pillar to pillar: another Le Corbusier point (la fenêtre en longueur);

The reason why these medieval buildings seem right to us today is their structures, which allowed functional versatility, and that is why we continue to protect them and try once again to recover them and give them new splendor.

\section{REFERENCES}

[1] Pérez-Mallaìna, P.E., La maestranza de artilleria y las atarazanas del azogue en los siglos XVIII y XIX. In: Boletín de la Real Academia Sevillana de Buenas Letras, 40,pp. 507-547, 2012.

[2] Bernardini, P.L., Fondaco Come Fondamento Di Civiltà: Rileggendo Olivia Remie Constable. Mediterranea - Ricerche storiche, 31, August 2014.

[3] Relazione Storico-Artistica/Venezia/Castello/Complesso dell'Arsenale, Ministero per i bene e le Attività Culturali, Soprintendenza per i Beni Architettonici e Paesaggistici di Venezia e Laguna (contents consulted on January 7, 2017 through the website available at http://arsenale.comune.venezia.it/)

[4] Quirós Castillo, J.A., La lettura stratigrafica dell'Arsenale Repubblicano di Pisa, in Scienza e Beni culturali XII (1996). Dal sito archeologico all'archeologia del costruito, Padova, pp. 133-143

[5] Gargano, G., Arsenali e scaria di Amalfi nel contesto del Meridione medievale. In Ricoveri per navi militari nei porti del Mediterraneo antico e medievale: atti del Workshop, Ravello, 4-5 novembre 2005, EDIPUGLIA, Bari, 2010

[6] Iborra, F. \& Miquel, M., La Casa de las Atarazanas de Valencia y Joan del Poyo. Anuario de Estudios Medievales, 37(1), pp. 387-409, 2007.

https://doi.org/10.3989/aem.2007.v37.i1.43 
[7] Aa.VV., Recuperando las Atarazanas/Un monumento para la Cultura, Junta de Andalucia, Sevilla, 1999.

[8] Nadal, E., La Drassana Reial de Barcelona. Evolució d'unaedificació cabdal del litoral barceloní. Barcelona Quaderns d'Història, 21, pp. 95-112, 2014.

[9] Johns, J., The tersāneat Alanya and the galleys of Charles d'Anjou. In Ricoveri per navi militari nei porti del Mediterraneo antico e medievale: atti del Workshop, Ravello, 4-5 novembre 2005, EDIPUGLIA, Bari, 2010

[10] Hvar Heritage Portal (contents consulted on January 9, 2017 through the website available at http://www.hvarheritage.com/it/cultural-heritage/arsenal)

[11] AA.VV., Recuperando las Atarazanas/Un monumento para la Cultura, Junta de Andalucia, Sevilla, 1999.

[12] Colletta, T., Arsenali navali marittimi e Musei delle città potuali mediterranee. In rivista TRIA, ${ }^{\circ}$ 46, pp. 135-150, 2008.

[13] This is the key objective of the Office Venice Arsenal (contents consulted on January 14, 2017 through the website available at http://www.comune.venezia.it) 